\title{
A Need Analysis of ESP materials for Agriculture Students at Indonesian Vocational School in West Sulawesi
}

\author{
Ibnu Hajar ${ }^{1}$, Anita Triastuti ${ }^{2}$ \\ ${ }^{1}$ Universitas Negeri Yogyakarta, Indonesia.e-mail: ibnuo6ibnu@gmail.com \\ ${ }^{2}$ Universitas Negeri Yogyakarta, Indonesia.e-mail:anitatria@uny.ac.id
}

\begin{tabular}{|c|c|}
\hline ARTICLE INFO & ABSTRACT \\
\hline $\begin{array}{l}\text { Keywords: } \\
\text { ESP, Indonesian } \\
\text { vocational school, } \\
\text { materials development, } \\
\text { Need analysis }\end{array}$ & $\begin{array}{l}\text { The development of industry in the modern era has led to the growth of } \\
\text { vocational schools in Indonesia. for that reason, vocational schools need to } \\
\text { adapt or change the general English (GE) learning materials into English } \\
\text { learning materials for specific purposes (ESP). therefore, this current study } \\
\text { aims to investigate the need for ESP materials for agriculture students at } \\
\text { Indonesian vocational schools. This study employed descriptive research to } \\
\text { describe the agriculture students'need for ESP materials. The participants of } \\
\text { this research were } 25 \text { students of XI grade agriculture students at vocational } \\
\text { school. This research used a questionnaire that was developed to find out the } \\
\text { ESP needs of agriculture students. Moreover, the data from the questionnaire } \\
\text { were analyzed by seeing the frequency of participants'answers then the data } \\
\text { were presented in the form of a chart orfigure. The results of the study showed } \\
\text { that the English learning objective of the agriculture students should make the } \\
\text { students able to communicate in English well. Then, English learning } \\
\text { materials for agriculture students should be blended with the agriculture } \\
\text { materials such as cultivation plants and processing agricultural products. } \\
\text { Also, English learning activities for agriculture students should involve } \\
\text { students actively by group work, making projects, and using current media } \\
\text { technologies in the learning process. Eventually, the results of this study can } \\
\text { be used as a reference in mapping and developing ESP materials especially for } \\
\text { agriculture students at vocational schools. }\end{array}$ \\
\hline
\end{tabular}

How to cite:

Hajar, I. \& Triastuti, A. (2021). A Need Analysis of ESP materials for Agriculture Students at Indonesian Vocational School in West Sulawesi. Indonesian Journal of English Language Teaching and Applied Linguistics, 6(1), 13-26

\section{Introduction}

In recent years, the previous study has shown that the development of vocational school trends in Indonesia has been increasing steadily. In 2018, there was a positive trend in terms of the ratio of senior high and vocational schools- with the ratio of 49.2\%:50.8\% (Suharno et. al, 2018). This is resulted by the rapid development of the industry in general and information and technology in particular. Therefore, the development of industry and technology, in general, requires vocational schools to develop the English language skills of their students. 
Such development demands changes or adjustments of the existing general English (GE) material in vocational schools into English for Specific purposes (ESP), especially to support the students' needs in their particular job field.

Regarding the important role of the ESP in the academic and employment situation, the curriculum must be structured considerably in line with the target language needs of students in their job or study environments (Lesiak-Bielawska, 2015). Moreover, the development of the latest ESP material for the vocational school must pay attention to practical linguistic approaches. For instance, it has to cover a communicative approach in their ESP materials design (Sokolova et al., 2015) and ESP materials design based on students' English proficiency level (Marcu, 2020). Such adaptations are expected to create English language materials that are not only suitable for students' English needs but also suitable for their future job skills.

Moreover, numerous experts have expressed their thought related to the central principle of ESP in English language teaching. In this case, Dudley-evans \& St. John (1998:6) provide a detailed ESP diagram that shows that ESP is an ELT branch. This diagram shows English for Specific Purposes (ESP) as a branch of English Language Teaching (ELT) which is specifically divided into two main branches. Those are English for Academic Purposes (EAP) such as science and technology, medical, legal purposes, management, finance, and economics, etc., and English for Occupational Purposes (EOP) such as workers, technicians, secretaries. etc. Although the objectives of the EAP and ESP are slightly different, the main purposes of ESP material development are choosing goals or objectives, materials, contents, and teaching methods that are appropriate to the student needs and their field of study.

To develop ESP materials, the needs analysis (NA) is the first and essential stage. Moreover, this is an initial stage to determine the next steps related to the development of learning materials. Needs analysis is often considered to be a necessity or a prerequisite that has become a critical and essential stage of the course development for either the general English course or the specific purpose (ESP) course (West, 1994). Moreover, As Akyel \& Ozek (2010) elaborated that Needs Analysis (NA) is a robust and efficient tool that helps teachers or researchers to clarify the basic needs of students. Such a tool opens wide possibilities for teachers and researchers to develop and adjust the curriculum that is suitable for students' need and their job field in particular.

Therefore, needs analysis is an important thing that becomes the main benchmark in this study to reveal the necessities, lacks, and wants to be associated with students. According to Hutchinson \& Waters (1987) there are two main concepts of needs which are target needs and learning needs. In short, the target needs refer to the learner's necessities, lacks, and wants for work successfully in the target situation; while learning needs concerns the learner's motivation and behavior, desired, personal reasons for learning, learning patterns, resources, and time availability.

In the Indonesian context, many studies have been conducted related to the needs analysis of ESP for various study programs in vocational schools. For instance, the needs analysis on tourism department in Indonesian vocational school (Asrifan et al., 2020), the needs analysis of writing material for office administration in vocational school (Yolanda et al., 2018), a need analysis for ESP-content materials for accountancy program at vocational school (Sukarni, 2019), ESP Teacher's and Student's perceptions on teaching speaking for a tourism program 
(Khoirunnisa et al., 2018), and also needs analysis of ESP for Tourism Study Program At senior vocational school (Oktarin \& Harahap, 2019). In particular, these studies have the objective to develop and design the ideal goals, topics, and learning materials in each respective study program to make students have the English skills needed for their future job skills.

However, after doing some preliminary observation throughout websites and online libraries, the researcher found that only a few studies explored ESP materials development for agriculture students at Indonesian vocational schools. In fact, according to the Research and Development Centre of Agricultural Land Resources (BBSDLP, 2017), the results of the 2017 Food Sustainability Index (FSI) research in the field of agriculture are very encouraging. Indonesia is ranked in the top 25 in the world, as the only ASEAN country surveyed and the results beat other big countries. Moreover, according to the Development of Quality Assurance Centre of Agricultural Vocational Education Indonesia ( $P_{4}$ tkpertanian, 2014) with the potential for natural resources and a supportive climate needs superior human resources to make agriculture the mainstay of national development. These results require the Indonesian education sector to develop suitable ESP materials to support students who will enter the job in the agriculture field.

Based on the information and conditions explained above, the researchers believe that is important to investigate students' needs for ESP purposes to help them adjust the English skills needed in the agriculture job field. Then, questions arise such as what kind of material do Indonesian vocational agriculture students needs? how to find the needs of agriculture students at Indonesian vocational schools? does the agriculture vocational school learning material support its graduates in their job field? Therefore, the objective of this present study is to use the need analysis (NA) approach to analyze ESP materials needs for agriculture students at Indonesian vocational schools to support them in their future job fields. In particular, this need analysis (NA) results are going to be employed as the basic data that will help teachers and researchers to develop curriculum or syllabus especially for agriculture programs for Indonesian vocational schools.

\section{Literature Review}

\subsection{Agriculture Program of Vocational High School}

The Curriculum 2013 (K-13) is the most recent curriculum used in Indonesian schools which is regulated by The Ministry of Education and Culture. According to the Law of Education System No. 20/2013, a program shall include approaches to meet such instructional goals. As a reference in the language teaching and learning process, Curriculum 2013 recommends several approaches. Those approaches are the scientific approach, discovery learning, problem-solving, project-based learning, and inquiry learning.

Moreover, according to the law of Education System No. 20/2013, the objective of education is to improve three components of students' competencies: attitude, knowledge, and skills. These competencies are summarized in the core competencies (KI), each of which contains one or more fundamental competencies (KD). The first and second core competencies (KI-1 and $\mathrm{KI}-2$ ) are used to improve students' religious and social competencies, whereas the third and fourth core competencies ( $\mathrm{KI}-3$ and $\mathrm{KI}-4)$ are used to improve students' knowledge and skills competencies. 
In general, agriculture is the broad term for everything that goes into growing crops and raising animals, to provide food and materials that people can use and enjoy. Farming, which involves cultivating the land and raising livestock, is one part of agriculture, which also includes plant science. To specify, Harris \& Fuller (2014, p.104) define the definition of agriculture more comprehensively, as follows: "Agriculture is the most comprehensive word used to denote the many ways in which crop plants and domestic animals sustain the global human population by providing food and other products. The English word agriculture derives from the Latin ager (field) and colo (cultivate) signifying, when combined, the Latin Agricultura: field or land tillage."

Moreover, the development of education and the need for practitioners in the field of agriculture have led many countries to develop vocational schools that are suitable for this field. Therefore, the Department of Agriculture at Vocational High School (SMK) was created, which is a department that prepares or trains students to have expertise in agriculture so that graduates from the agriculture department are ready to work. SMK Department of Agriculture actually has many more specific majors, in the 2013 Curriculum the name "Department" has been changed or renamed to Expertise Competence, but most people are more familiar with the word "Department" so that the word Department is still often used instead of Expertise Competence.

The Department of Agriculture has specifications in accordance with the expected competencies. According to the Regulation of the Director-General of Primary and Secondary Education Number, Ministry of Education and Culture Number: 07 / D.D5 / KK / 2018 Date: June 7, 2018, concerning the Structure of the Vocational Secondary Education Curriculum for the Department of Agriculture, is divided into (a) Expertise: Agribusiness and Agrotechnology (b) Expertise Program: Plant Agribusiness (c) Expertise Competencies: (Food Crops and Horticulture Agribusiness, Plant Restoration and Seedling Plantations, Ecological Organic Agribusiness, Recovery and Seed 4 Years of Ecological Organic Agribusiness).

\subsection{English for Specific Purposes (ESP)}

English for Specific Purpose (ESP) is described as the teaching and learning of English as a second or foreign language where the learners' aim is to use English in a specific subject. It is a method of teaching and studying English for advanced topics with vocational and educational goals. As mentioned by Paltridge \& Starfield (2014, p.2) that ESP has now expanded to include other areas such as English for academic purposes (EAP), English for occupational purposes (EOP), English for vocational purposes (EVP), English for medical purposes (EMP), English for business purposes (EBP), English for legal purposes (ELP), and English for sociocultural purposes (ESCP). Regarding the above statements, the variety of language purposes is the main reference for developing ESP materials that are in accordance with certain language learning objectives.

Moreover, the language learning objectives and the characters of ESP for each area of course differ depending on the needs of each area. However, the specific objectives or main characteristics of ESP can be found on Dudley-Evans \& St. John (1998, p.4-5), as follows: (a) ESP programs are designed to cater to the discipline- or vocation-specific needs of learners with a different level of language ability to communicate for work or study purposes in specific disciplines. (b) The programs are informed by a theoretical orientation (approach) 
along with instructional design (design and procedure). (c) ESP materials and methods are developed or adapted to provide learners with needs responsive instruction. (d) ESP centers on a myriad of disciplinary knowledge, language, genres, discourses as social practices, and situational specificity. (e) Both language and activities are appropriate to particular disciplines. ( $f$ ) In ESP programs, students learn knowledge or concepts from their discipline or specialization. (g) These programs require the students to learn to recognize how language operates within genres and sub-genres in this discipline or specialization.

One distinguishing characteristic of an ESP course is that its material and objectives are adjusted to the specific needs of the learners. The language, skills, and genres should be suitable to the particular tasks the learners must carry out in English. ESP students are usually (but not always) adult learners. They are often a homogeneous category in terms of learning objectives, but not necessarily in terms of language proficiency.

\subsection{Needs Analysis of ESP Materials Development}

Needs analysis is the most common feature of ESP; it is commonly known as a criterion or a core feature of ESP that was typically based on the goal or end of a course requirement, and it is typically to look at actual learners' initial needs. According to Brown (1996), there are three main objectives of need analysis. First, it is a means of providing broader insight into the content, design, and application of a language program. Second, it may be applied to the development of goals, strategies, and material. Third, it can be used to evaluate a current curriculum.

In terms of ESP needs analysis, Hutchinson \& Waters (1987) proposed a clearer difference which consists of two main concepts (target needs and learning needs). Target needs deal with the main things that students need to do in the target situations and purpose. Moreover, the target needs consist of three main useful terms which are niceties, lack, and wants. In general, necessities deal with the type of needs related to the demands of the target situation, lack a deal with the students lacks in a target situation, and want a deal with groups (students, teacher, sponsors) point of view and interest in ESP course design. In addition, target needs refer to the knowledge and skills that students require to achieve the target situation.

\section{Research Methodology}

This study used descriptive research as the way to investigate the current issue. The descriptive research design was utilized in this study to give solutions to the research problems. Descriptive research entails obtaining data that characterizes occurrences and then organizing, tabulating, depicting, and describing the data (Glass \& Hopkins, 1984). This research strategy is employed because it frequently uses visual aids such as graphs and charts to assist the reader in comprehending the data distribution.

\subsection{Participants}

This current study took place in SMK Negeri 1 Tapango, West Sulawesi, Indonesia. The participants of this research were the XI grade agriculture students of SMKN 1 Tapango. The researcher chose the participant based on the preliminary observation in the school and also based on the need for continuity of ESP materials to support students in their next grade and future job field. Moreover, the participants were 25 students consisting of 18 female and 7 male students. 


\subsection{Instruments}

This research used a questionnaire to obtain the data. The questionnaire was developed to find out the ESP needs of the agriculture program at vocational school which is consists of 8 main questions. The questionnaire was distributed to the XI grade students of the agriculture program at SMKN 1 Tapango.

\subsection{Data Analysis Procedures}

The result of the questionnaire was analyzed by seeing the frequency of the participants' opinions and views about their needs, lacks, and wants in English. The statistical devices employed for analyzing those data means and percentages. Then, the researcher presented the data in the form table or chart.

\section{Findings}

\subsection{ESP Needs Analysis of Agriculture Students}

The questions in the questionnaire are an extension of the questions about ESP needs analysis; needs, and lacks. where these questions are designed to find and match the needs of vocational school students, especially those who are participating in agricultural programs. The questions can be seen in the table below, as follows:

Table 1: Questions of ESP Needs Analysis for Agriculture Students

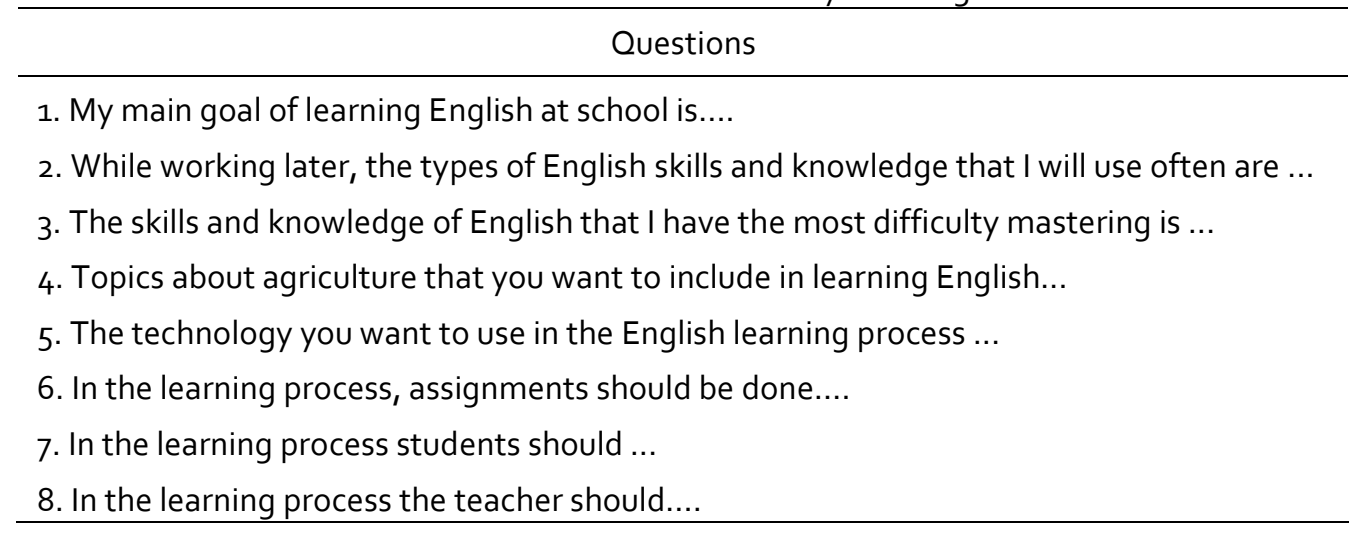

\subsection{English Learning Objective of Agriculture Students at Vocational School}

The English learning objective of students especially for ESP objective is formulated by considering several factors such as students' main goal in learning English, types of English skills and knowledge that students will use often while they are working later in their job field, and also the most difficult skills and knowledge of English for students to master. Researchers have explained and summarized the results of the questionnaire related to the considered factors in the form of a graph for easier understanding as follows.

The results of the first question about the main objectives of agricultural students in learning English showed that about $64 \%$ of students choose to learn English to be able to communicate in English well. Then, about $16 \%$ of students choose to learn English to be able to understand reading in English. about $12 \%$ of students learn English to be able to understand the grammar in English. And then, about $8 \%$ of students choose their reason or other reason. 
A Need Analysis of ESP materials for Agriculture Students

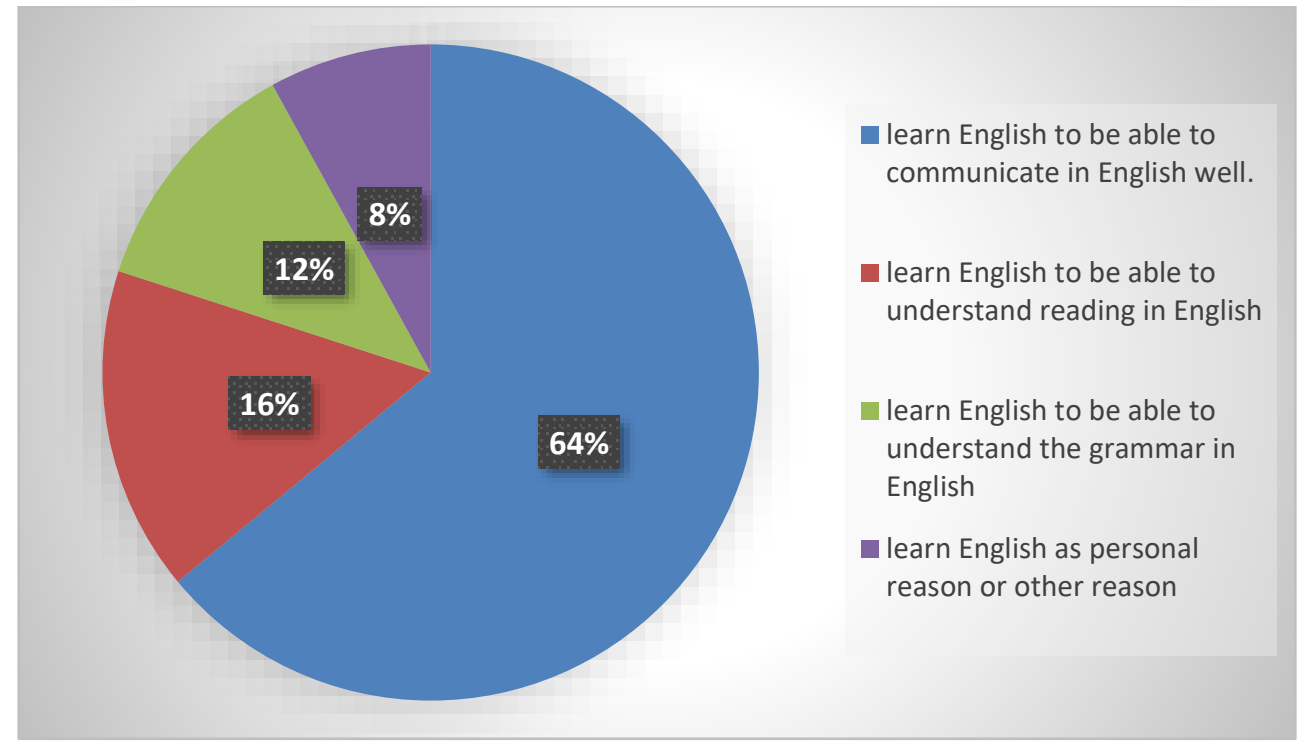

Figure 1: Agriculture Students' main goal in learning English

The results of the second question about the types of English skills and knowledge that students will use often while they are working later in their job field showed that about $64 \%$ of students choose speaking. Then, about $12 \%$ of students choose listening. About $8 \%$ of students choose writing and pronunciation. And then, about $4 \%$ of students choose vocabulary and reading.

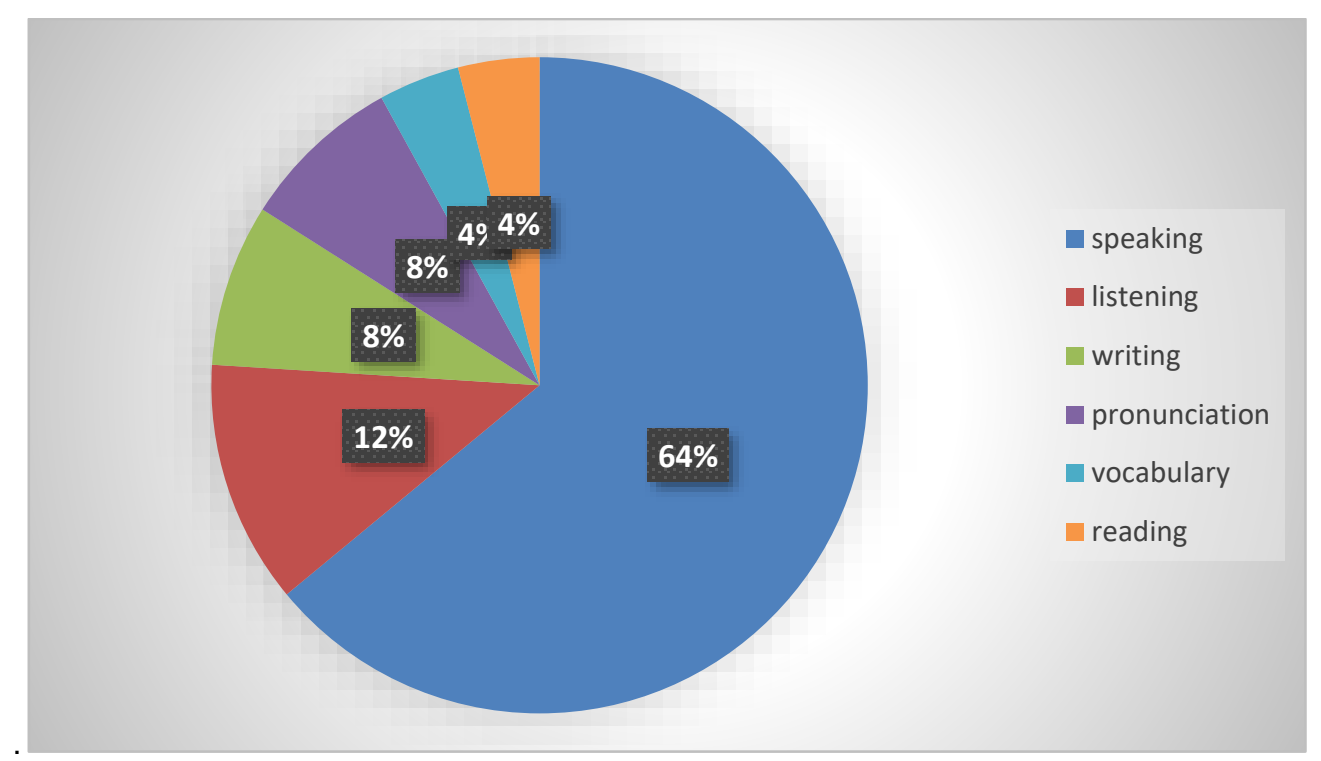

Figure 2: Types of English skills and knowledge that students will use often while they are working later

The results of the third question about the most difficult skills and knowledge of English for students to master showed that about $64 \%$ of students choose speaking. Then, about $12 \%$ of students choose listening. About $8 \%$ of students choose writing and pronunciation. And then, about $4 \%$ of students choose vocabulary and reading. 


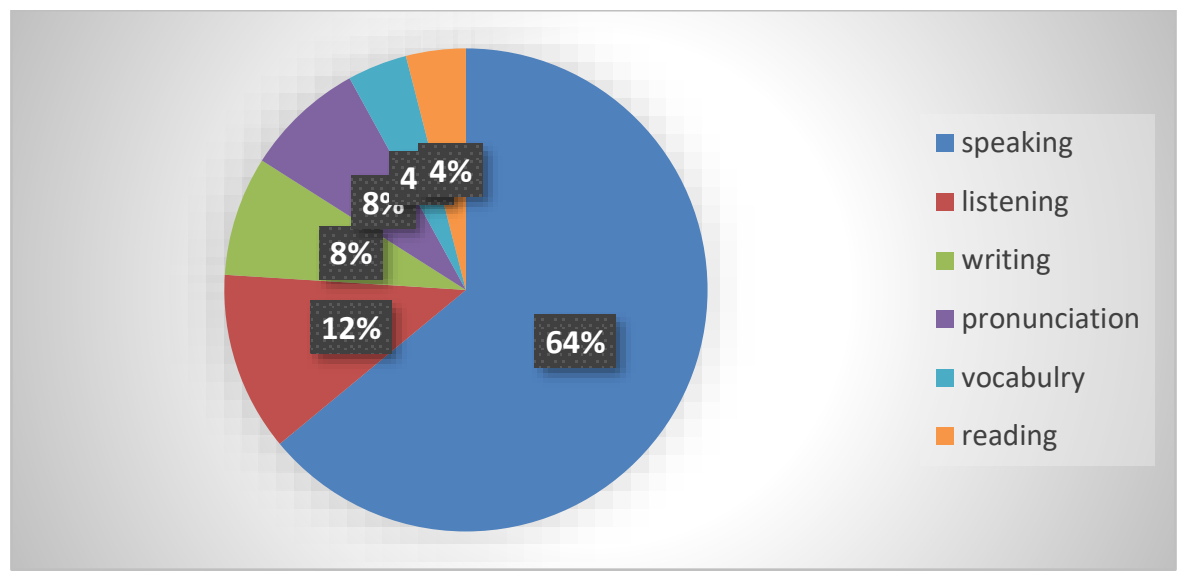

Figure 3: The most difficult skills and knowledge of English for students to master

The results of the fourth question about topics about agriculture that students want to be included in learning English showed that about 32\% of students choose cultivate plants. Then, about $24 \%$ of students choose processing agricultural products. About $20 \%$ of students choose operate a tool related to agriculture other than a tractor. About $16 \%$ of students choose the agronomy business. And then, about $8 \%$ of students choose fertilizer and pesticide.

From the description above, the tendency of students' learning goals in English is mostly to be able to communicate in English well, the tendency of English skills needed by students in their job field is speaking. however, they also tend to have difficulty mastering speaking skills. The formulation of the English learning objective for agriculture students at vocational schools was discussed in the discussion session.

\subsection{English Learning Materials for Agriculture Students at Vocational School}

The English learning materials especially ESP materials for agriculture students are formulated by considering several factors such as topics about agriculture that students want to be included in learning English, the technology students want to use in the English learning process, and also the form of assignments completing during the learning process proses. Researchers have explained and summarized the results of the questionnaire related to the considered factors in the form of a graph for easier understanding as follows.

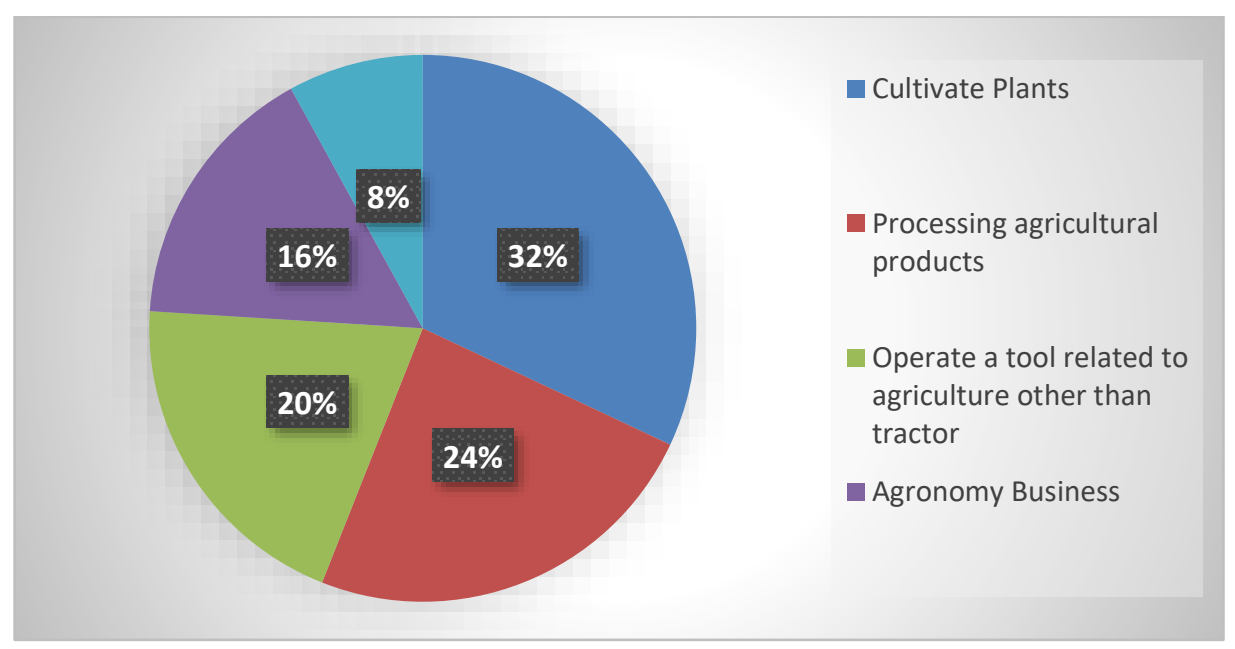

Figure 4: Topics about agriculture that students want to be included in learning English 
The results of the fifth question about the technology students want to use in the English learning process showed that about $40 \%$ of students choose electronic media such as computers and projectors. Then, about $32 \%$ of students choose social media (Instagram, WhatsApp, Facebook). About 20\% of students choose e-books (PDF books). And then, about $8 \%$ of students choose online games (Kahoot, Quizizz).

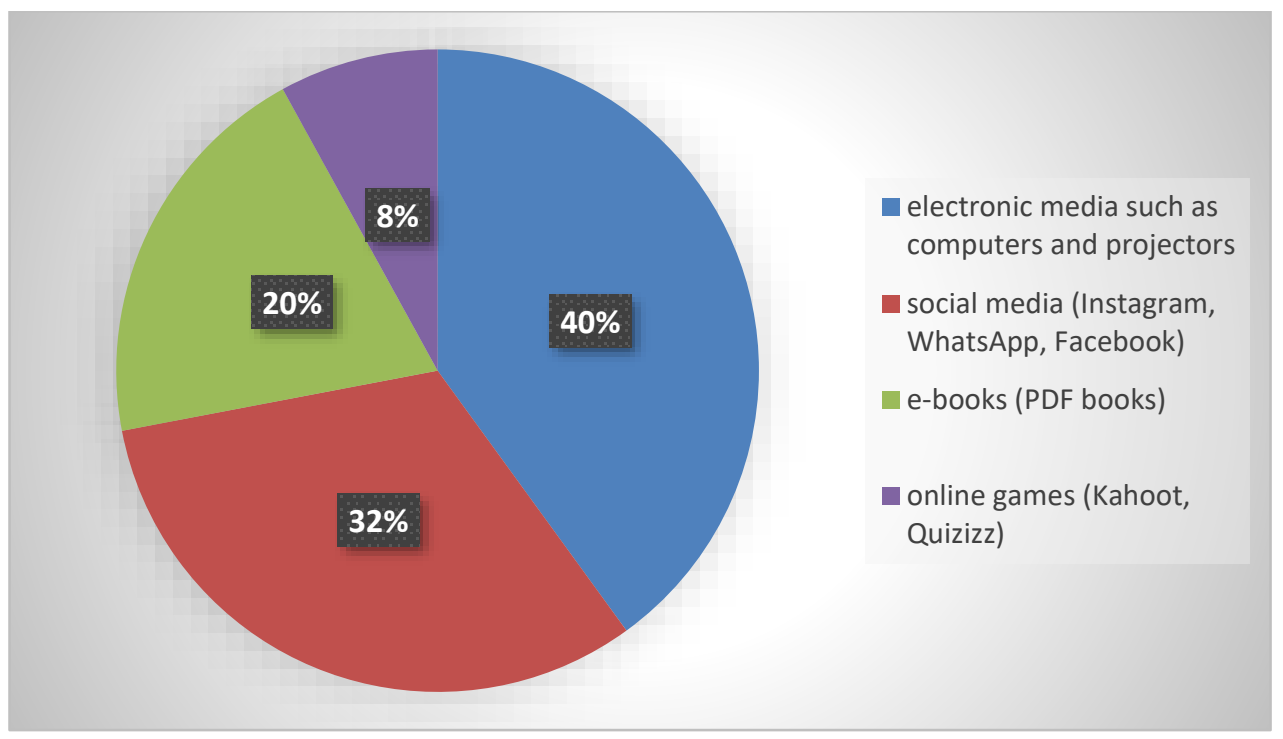

Figure 5: The technology students want to use in the English learning process

The results of the sixth question about the form of assignments completing during the learning process proses showed that about $44 \%$ of students choose individual. Then, about $28 \%$ of students choose the small group (4-6 people). About $20 \%$ of students choose pairs ( 2 people). And then, about $8 \%$ of students choose the large group ( 5 people or more).

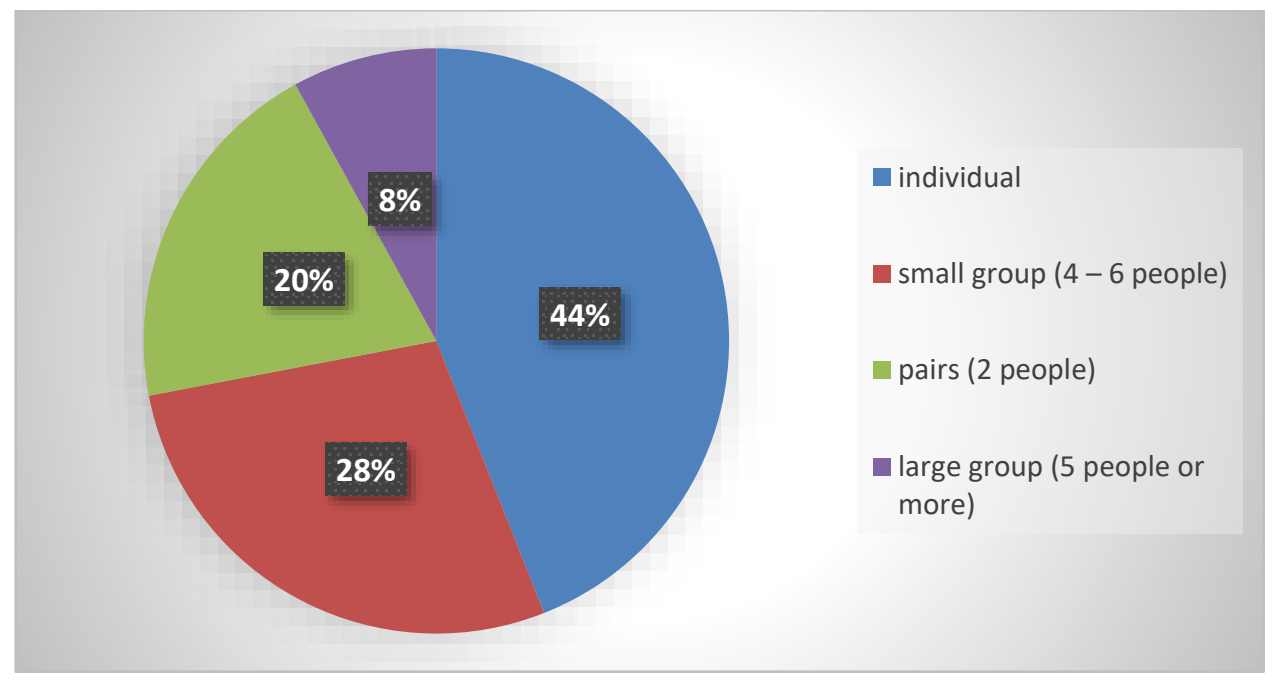

Figure 6: The form of assignments completing during the learning process proses

The results of the seventh question about things that students should do during the learning process showed that about $64 \%$ of students choose actively participate in the learning process. Then, about $24 \%$ of students write down or record everything the teacher explains. About $4 \%$ of students choose to study independently and work on tasks calmly. About $4 \%$ of 
students choose just to listen to the teacher's explanation. And then, about $4 \%$ of students choose summarizing and work on the task.

\subsection{English Learning Activities for Agriculture Students at Vocational School}

The English learning activities especially for agriculture students are formulated by considering several factors such as activities students should do during the learning process and activities teachers should do during the learning process. Researchers have explained and summarized the results of the questionnaire related to the considered factors in the form of a graph for easier understanding as follows.

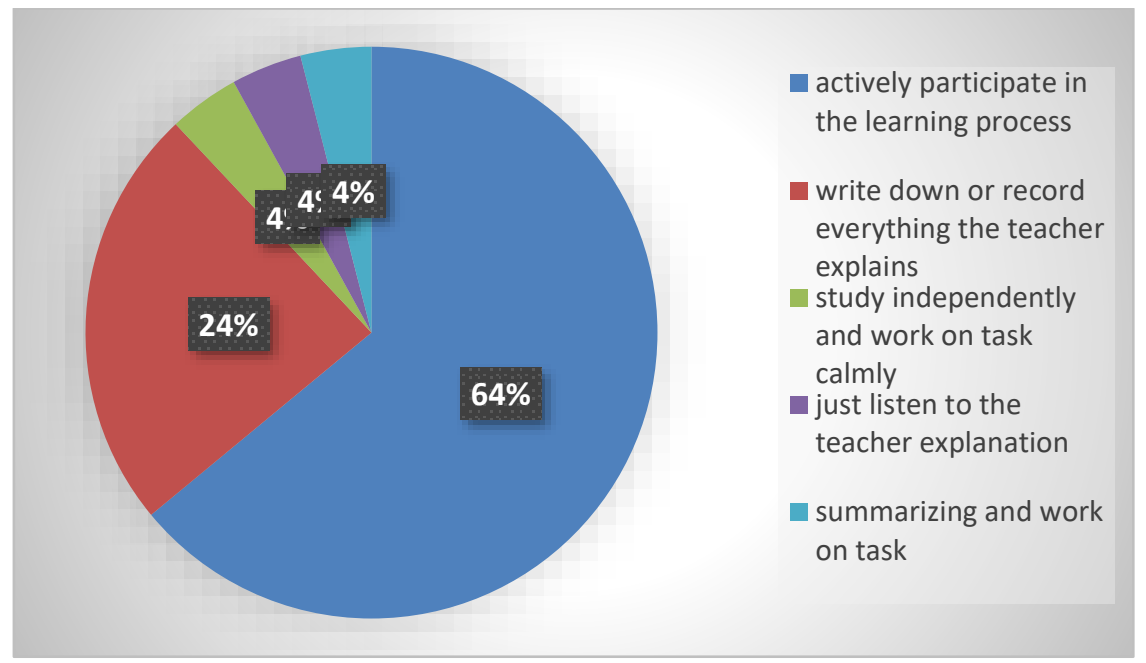

Figure 7: Things that students should do during the learning process

The results of the last question about Students' perspectives on what things teachers should do during the learning process showed that about $52 \%$ of students choose the teacher to read the text and interpret it directly with the students. Then, about $32 \%$ of students choose the teacher to explain the formula and ask students to do the practice questions. About $8 \%$ of students choose the teacher to move around the classroom while controlling student work and making comments. And then, about $8 \%$ of students choose the teacher to guide students in discussing the text.

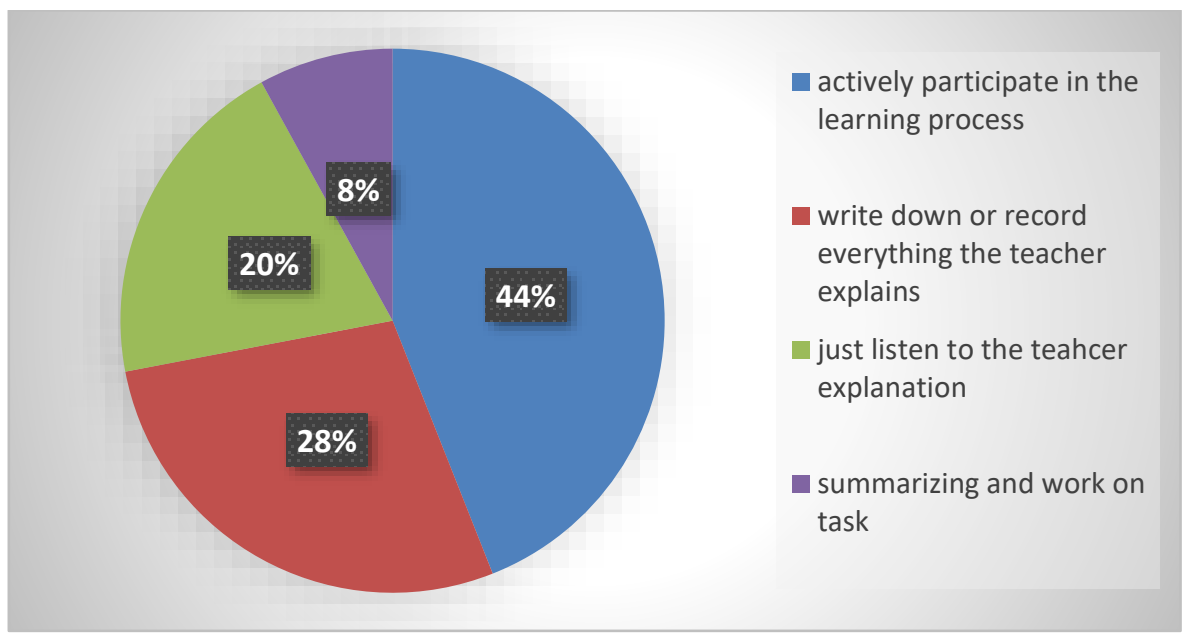

Figure 8: Students' perspective on what things teachers should do during the learning process 


\section{Discussion}

\subsection{English Learning Objective of Agriculture Students at Vocational School}

Based on the results of the study, it showed that most of the students have the main goal of learning English to speak English well (see figure 1). As we know that in the era of globalization which allows us to get information from all over the world and communicate with various people around the world speaking English which is an international language is crucial. Brumfit (2001:35) stated that "English is an international language that it is the most widespread medium of international communication". therefore, it is not surprising that students choose the goal of learning English to be able to communicate well.

Moreover, the result of the study showed that agriculture students need speaking skills often while they are working later in their job field (see figure 2). The perspective of these students is most likely due to the development of the industry, especially the agricultural industry that prioritizes modern technology and also requires students to have qualified skills to compete in the global era. One of the main English skills that students need is the ability to speak well.

However, the result of the study also showed that the students considered speaking as the most difficult skill. According to Bueno et al. (2006: 321), "Speaking is one of the most difficult skills language learners have to face". Therefore, it is necessary to design learning with particular goals and communicative approaches so that students can practice speaking English more. When developing course material, ESP teachers need to understand the students' goals and objectives (Dardig, 2015).

\subsection{English Learning Materials for Agriculture Students at Vocational School}

Based on the result of the study, it showed that agriculture students were most interested in including learning about cultivation plants followed by processing agricultural products in their English learning material (see figure 4). Therefore, the material that will be designed for them is material that emphasizes a communicative approach by paying attention to these agricultural learning materials. A communicative method should be used in English education since the objective is for learners to become communicatively competent in their specialty field (e.g., agriculture). As a result, to implement such an approach, materials connected to communicative purpose applicable to classroom activities must be developed (LarsenFreeman, 2013)

In addition to designing materials that suit the needs of students, learning media also needs to be adapted to the needs of students. The results showed that students were more likely to like the use of conventional media such as computers and projectors (see figure 5). However, learning media must still pay attention to the development of modern ICT such as online social media, online books, and online games (e.g., Kahoot, Quizizz). As Huda et al. (2020) stated in their study that the usage of social media would allow students to access information at any time and from any location, therefore it boosts the efficacy of education.

\subsection{English Learning Activities for Agriculture Students at Vocational School}

One aspect that also needs to be considered in developing learning materials is the activity in the learning process. The result of the study showed that most students agreed that the learning process in the classroom should involve students actively (see figure 8 ). Activities that can be done to make students more active can be done by giving students the practice 
of making projects in groups. Although students prefer to work on assignments individually (see figure 7), still group work should be the main activity to increase student activity in the learning process. According to some studies, collaborative learning has swiftly become a powerful supporter of group work in educational institutions of all levels (Gamzon,1994; Sofroniou \& Poutos, 2016). Therefore, the activities that are designed later for vocational school agriculture students need to pay attention to the forms of these activities so that the English learning process can be in accordance with the predetermined ESP objectives.

\section{Conclusion}

Based on the results of the study, it can be concluded that the vocational school students, in this case, agriculture students, need English learning material that is suitable for their needs in agriculture fields. the needs analysis showed that the English learning material for agriculture students should consider the learning activity that promotes students' speaking ability to make them able to speak English well. Moreover, the learning materials also need to be embedded with agriculture materials such as how to cultivate plants and how to processing agriculture products. Also, the needs analysis showed that the Learning activities should be designed so that students can actively participate in classroom interaction and also teachers must be able to directly help students who have difficulties, especially in translating text and words.

Nevertheless, since this study is only conducted in a small testing group, $\mathrm{XI}$ agriculture program of SMK Negeri 1 Tapango, it is strongly suggested to future studies find more participants. It might illustrate broader data related to the teaching materials needs, especially for agricultural students in vocational schools. Lastly, another consideration is that due to time limits, this study can only be carried out in the need analysis stage. It is hoped that future studies can develop teaching materials based on the need analysis that has been obtained.

\section{References}

Akyel, A. S., \& Ozek, Y. (2010). A language needs analysis research at an English medium university in Turkey. Procedia-Social and Behavioral Sciences, 2(2), 969-975.

Askar, K. (2013). Reformulating English for Specific Purposes (ESP) in Indonesia: Current issues and future prospects. Proceedings of ISELT FBS Universitas Negeri Padang, 1, 3648.

Asrifan, A., Vargheese, K. J., Syamsu, T., \& Amir, M. (2020). ESP course design: the need analysis on tourism department in Indonesia vocational high schools. Journal of Advanced English Studies, 3(2), 69-77.

BBSDLP. (2017) as cited on Monday, 15th March 2021 from http://bbsdlp.litbang.pertanian.go.id/ind/index.php/layanan-mainmenu-65/infoterkini/656-pertanian-indonesia-masuk-peringkat-25-besar-dunia1

Bueno, A., D. Madrid and N. McLaren (2006). TEFL in Secondary Education. Editorial Universidad de Granada.

Brumfit, (2001). Individual Freedom in Language Teaching. Oxford University Press.

Creswell, John W. (2014). Research design (qualitative, quantitative, mixed method approaches). University of Nebrasca- Lincoln. America. United State 
Dardig, M. H. (2015). Using the Communicative Language Teaching Approach (CLT) in Teaching English for Specific Purposes (ESP). Journal of American Science, 11(3).

Gamson, Z. F. (1994). Collaborative learning comes of age. Change: The Magazine of Higher Learning, 26(5), 44-49.

Glass, G. V., \& Hopkins, K. D. (1984). Test Bank for Statistical Methods in Education \& Psychology (2nd ed.)

Dudley-Evans, T., St John, M. J., \& Saint John, M. J. (1998). Developments in English for specific purposes: A multi-disciplinary approach. Cambridge university press.

Harris, D. R., \& Fuller, D. Q. (2014). Agriculture: definition and overview. Encyclopedia of global archaeology, 104-113.

Hutchinson, T., \& Waters, A. (1987). English for specific purposes. Cambridge university press.

Khoirunnisa, K., Suparno, S., \& Supriyadi, S. (2018). Exposing ESP Teacher's and Students' Perception about Teaching Speaking for Tourism Program. Dinamika Ilmu: Jurnal Pendidikan, 18(1), 37-49.

Huda, S. S. M., Kabir, M., \& Siddiq, T. (2020). E-Assessment in Higher Education: Students' Perspective. International Journal of Education and Development using Information and Communication Technology, 16(2), 250-258

Larsen-Freeman, D., \& Anderson, M. (2013). Techniques and principles in language teaching 3rd edition-Oxford handbooks for language teachers. Oxford university press.

Lesiak-Bielawska, Elzbieta Danuta. (2015). Key aspects of ESP materials selection and design. English for Specific Purposes World, ISSN 1682-3257, www.espworld.info, Issue 46, 2015.

Malley, J., \& Keating, J. (2000). Policy influences on the implementation of vocational education and training in Australian Secondary Schools1. Journal of Vocational Education and Training, 52(4),627-652.

Marcu, N. A. (2020). Designing Functional ESP (English for Specific Purposes) Courses. Procedia Manufacturing, 46, 308-312.

P4TKPERTANIAN KEMDIKBUD (2014) as cited on Monday, 15th March 2021 from http://p4tkpertanian.kemdikbud.go.id/menyelaraskan-dunia-pendidikan-dan-duniakerja-di-bidang-pertanian/

Paltridge, B., \& Starfield, S. (Eds.). (2014). The handbook of English for specific purposes. John Wiley \& Sons.Rata, georgeta. Florin sala. Et al. (2012). Agriculture English. Cambridge Scholars Publishing.

Oktarin, R., \& Harahap, A. (2019). Needs Analysis of ESP for Tourism Study Program At Smkn 7 (Senior Vocational School) Kota Bengkulu. Journal of English Education and Teaching, 3(1), 14-28.

Sofroniou, A., \& Poutos, K. (2016). Investigating the effectiveness of group work in mathematics. Education Sciences, 6(3), 30.

Sokolova, E. Y., Golovacheva, E. A., \& Chernaya, A. A. (2015). Professionally-oriented communicative language teaching approach by the design of a computer assisted ESP course: analysis of results. Procedia-Social and Behavioral Sciences, 215, 191-195.

Suharno, S., Pambudi, N. A., Widiastuti, I., \& Harjanto, B. (2018). Apprenticeship Implementation of Productive Teacher at Vocational School in Indonesia. In 5th UPI International Conference on Technical and Vocational Education and Training (ICTVET 2018) (pp. 88-95). Atlantis Press. 
Sukarni, S. (2019, April). A Need Analysis for ESP-content Materials for Accountancy Programme at Vocational High School. In ELLiC 2019: Proceedings of the 3rd English Language and Literature International Conference, ELLiC, 27th April 2019, Semarang, Indonesia (p. 144). European Alliance for Innovation.

West, R. (1994). Needs analysis in language teaching. Language teaching, 27(1), 1-19.

Yolanda, I., Ngadiso, N., \& Sumardi, S. (2018). Writing Material for Office Administration Study Program in Vocational High School: Students' Need Analysis. Journal of English Education, 3(2), 89-99. 